\title{
MULTIPATERNIDADE SOB A ÓTICA DO ORDENAMENTO JURÍDICO POSITIVO
}

\author{
Luciano Maia Bastos ${ }^{1}$ \\ Francisco Caetano Pereira ${ }^{2}$
}

Resumo: O presente trabalho visa analisar a possibilidade da aplicação da dupla paternidade dentro do ordenamento jurídico pátrio, a partir da apresentação histórica e evolutiva dos conceitos de família e de filiação. Para tanto, utiliza-se o método dedutivo. O conceito de família sofreu mudanças ao longo da história, tendo alterada, sobretudo, a sua função, visto que hoje a família é encarada como o lócus da realização pessoal de seus membros. Por conseguinte, o legislador necessitou adaptar-se a tais mudanças, o que ocasionou diversas evoluções legislativas até os tempos atuais.

Palavras-chave: Filiação; Paternidade; Afetividade; Multiparentalidade; Registro.

\section{MULTIPATERNITY UNDER OPTICAL LEGAL ORDINANCE}

Abstract: The present work aims to analyze the possibility of the application of dual paternity within the legal order of the country, based on the historical and evolutionary presentation of the concepts of family and sonship. For that, the deductive method is used. The concept of the family has undergone changes throughout history, having altered, above all, its function, since today the family is seen as the locus of the personal fulfillment of its members. Therefore, the legislator needed to adapt to such changes, which has led to various legislative developments up to the present time.

Keywords: Affiliation; Paternity; Affectivity; Multiparentality; Record.

\footnotetext{
${ }^{1}$ E-mail: luciano@maiabastos.com.br. Av. Presidente Affonso Camargo, no 2125 - Sala B - Cristo Rei - Curitiba - PR - Brasil - CEP: 80.050-370. Doutorando em Direito e Ciências Socias - Universidade Nacional de Córdoba - UNC; Mestre em Direito pela Universidade do Vale do Itajaí; Mestrando em Direito Internacional pela Universidad Autónoma de Asunción; Especialista em Processo Civil pelo Centro Universitário Autônomo UNIBRA; Especialista em Direito Tributário pelo Instituto de Ciências Sociais do Paraná - ICSPR; Advogado.

${ }^{2}$ Pós-doutor pela Universidade Federal de Pernambuco; Doutor em Direito pela Universidad de Desto - Espanha;
} 


\section{INTRODUÇÃO}

Nos dias atuais, a temática familiar é recorrente em decisões inovadoras de todas as instâncias processuais, revendo antigos conceitos até então tidos como verdades absolutas e abandonando paradigmas que não mais se aplicam à realidade contemporânea.

O instituto familiar sofreu intensas modificações em sua forma de estruturação na recente história do Brasil, fazendo-se necessária a observação das mesmas para um correto aperfeiçoamento do Direito de Família. Neste sentido, pretende-se discorrer acerca da nova conjuntura social familiar, na qual se verifica o advento do afeto como valor jurídico digno de proteção, nos termos da Constituição Federal de 1988.

Dentro do espectro familiar, destaca-se a filiação como o objeto de estudo deste trabalho, analisando-a sob o enfoque de cada um dos diferentes critérios que a embasam, quais sejam: critério registral, critério biológico e critério afetivo, bem como a forma de resolução dos conflitos que ocorram entre tais critérios uma vez que estes não coincidam em uma mesma paternidade.

É nesse aspecto que reside a principal indagação deste trabalho: é necessária a escolha por apenas uma única paternidade singular quando da colisão entre diferentes critérios?

O presente busca como seu objetivo específico averiguar acerca da possibilidade de os deveres e direitos da paternidade vier a ser atribuídos de forma plural, isto é, se há espaço dentro do ordenamento jurídico para se conceber o instituto da dupla paternidade ou até mesmo da multiparentalidade, o qual se consubstancia na possibilidade de um mesmo filho possuir dois pais, recebendo maior enfoque, neste estudo, o viés paternal.

Na resposta desta indagação, parte-se da premissa de que, uma vez inserida no contexto contemporâneo do Direito de Família, a paternidade já não pode mais ser atribuída exclusivamente pela análise de um único critério de filiação, considerando-se que todos eles surtem efeitos das mais variadas naturezas na vida do indivíduo cuja paternidade se discute.

Ademais, há de ser levada em consideração na atribuição da paternidade a dignidade das pessoas envolvidas, e, acima destas, a prevalência da observância dos interesses da criança e do adolescente, prevista pela Constituição Federal em ser artigo 227 e reafirmada legislativamente através do Estatuto da Criança e do Adolescente (Lei 8.069) de 1990.

Por fim, há de se admitir que o reconhecimento da dupla paternidade gerará uma infinidade de repercussões jurídicas, tanto de natureza moral quanto de natureza patrimonial, 
sendo necessário um estudo que contemple a abrangência destes efeitos decorridos do vínculo de filiação.

Ainda que o tema já apresente discussões na doutrina e na jurisprudência, tal tem ocorrido de forma tímida, demonstrando-se necessidade de pronunciamento legislativo para pacificar a questão. Nesse sentido, visualizando-se a relevância do tema por envolver valores fundamentais, e o dissenso, em especial, jurisprudencial, quanto à hipótese de dupla paternidade, um estudo unificado na academia se apresenta inovador.

Visualizando-se as discussões doutrinárias e jurisprudenciais relativamente recentes sobre o tema, controversa resta à questão, instigando-se o interesse pela pesquisa e por análise mais completa sobre o tema, e nesse tocar se incentiva o proceder do presente estudo científico.

Este trabalho será realizado através do método dedutivo, com a leitura de doutrina, legislação e jurisprudência. A técnica para a elaboração da pesquisa será a prescritiva, baseando-se em um referencial teórico bibliográfico de diversos autores da área em estudo, legislação e jurisprudência. As citações serão efetuadas a partir do sistema autor/data.

\section{A POSSIBILIDADE DE DUPLA PATERNIDADE}

$\mathrm{O}$ aspecto principal que esta monografia almeja averiguar consiste na possibilidade ou não da coexistência harmoniosa de duas paternidades distintas, e por distintas entenda-se: composta por distintos pais, e não critérios, visto que conforme á analisado no capítulo anterior, toda e qualquer paternidade, independentemente de sua origem, necessita obrigatoriamente estar respaldada no critério afetivo.

De acordo com Lôbo (2008, p. 06), uma das mais importantes mudanças ocorridas em virtude da promulgação da Carta Constitucional de 1988 foi a transformação da natureza socioafetiva em gênero, abrangendo tanto as espécies biológica quanto a não biológica. Assim o sendo, o que se distingue é a paternidade puramente socioafetiva da socioafetiva de origem biológica.

Todavia, embora venha se consolidando na doutrina e na jurisprudência o entendimento de que a paternidade socioafetiva prevalece frente às demais, tal ainda não resta pacificado, pois, conforme pregam Andrigui e Krueguer (2006, p.84), "não há, na Constituição Federal, referência de primazia entre afetividade e consanguinidade. Existem, assim, duas verdades reais: a biológica e a socioafetiva". Neste mesmo vértice posiciona-se Santos (2009, p.343), que com maestria esclarece:

Revista de Direito de Família e Sucessão | e-ISSN: 2526-0227 | Porto Alegre | v. 4 | n. 2 | p. 120 - 137 | Jul/Dez. 2018 
Destarte, de se reconhecer que tanto a filiação biológica como a socioafetiva encontram guarida na Constituição Federal de 1988. Na maior parte dos casos, a biológica também envolverá o afeto - que estará presente desde o surgimento do vínculo. Na socioafetiva, por sua vez, o sentimento de afeto é construído ao longo da vida, porque se quis e desejou. Há um projeto comum, que permite a integração e pleno desenvolvimento pessoal e social de cada partícipe da entidade familiar. (grifouse).

Ademais, há de se considerar que a existência de uma paternidade socioafetiva não exime de responsabilidade o pai biológico, quanto as suas obrigações morais e patrimoniais. Neste sentido, extrai-se do acórdão n 70039013610 do TJRS:

Incabível a alegação de existência de paternidade socioafetiva com terceiro para eximir o pai biológico das suas obrigações morais e materiais perante a filha. A ação foi proposta quando a investigante tinha 13 anos de idade e desde que soube a verdade sobre sua origem procurou aproximação com o apelante antes do aforamento da demanda, sem qualquer oposição por parte do pai registral. Não pode o apelante se valer da paternidade socioafetiva, desvirtuando sua finalidade de evitar que os filhos reconhecidos simplesmente de um momento para outro fiquem sem pai, para continuar se eximindo de suas obrigações de pai em relação à apelada, preterida desde o nascimento. A filiação socioafetiva, tão festejada na jurisprudência, não se presta a socorrer o mesquinho interesse material do apelante, que quer continuar negando à filha os direitos que lhe pertencem: nome, alimentos e herança. NEGARAM PROVIMENTO À APELAÇÃO. UNÂNIME. (Apelação Cível No 70039013610, Oitava Câmara Cível, Tribunal de Justiça do RS, Relator: Luiz Felipe Brasil Santos, Julgado em 24/02/2011).

Por óbvio que o ideal seria que todos os critérios de filiação, quais sejam, o registral, o biológico e o afetivo, coincidissem em um único sujeito, vindo uma mesma pessoa a desempenhar a função parental na vida da criança.

Fachin (1996, p.37), defende que "a verdade sociológica da filiação se constrói. Esta dimensão da relação paterno-filial não se explica apenas na descendência genética, que deveria pressupor aquela a serem coincidentes". Da mesma sorte é o posicionamento de Madaleno (2011, p.472) , ao dizer que "a filiação consanguínea deve coexistir com o vínculo afetivo, pois com ele se completa a relação parental". 
Cysne (2008, p.206) sintetiza tal pensamento com suas palavras, ao dizer que "o ideal é que as diversas espécies de filiação encontrem-se unidas, isto é, que o vínculo da filiação seja biológico, jurídico e socioafetivo".

Todavia, diante da realidade que se verifica na Sociedade contemporânea, observa-se um número cada vez maior de situações em que tal coincidência não se dá, cabendo, então, ao Direito prever mecanismos para melhor regular estas situações, conferindo segurança jurídica aos envolvidos nessas relações e, em especial, às crianças, muitas vezes vítimas de disputas judiciais.

O que não se pode, entretanto, é atribuir, de forma abstrata, hierarquia entre os critérios de fixação da filiação. Ademais, um critério não é, necessariamente, excludente do outro. Em determinadas situações esses critérios poderão se complementar e viabilizar a pluralidade de paternidades/maternidades, ou seja, a multiparentalidade. (ALMEIDA e RODRIGUES JÚNIOR, 2012, p.103)

Neste sentido é a lição de Madaleno (2011, p.479), para o qual “não é suficiente a mera verdade biológica, pois ela deve coexistir com a prevalente verdade afetiva, que a completa com a verdade registral da filiação".

Destarte, indaga-se qual paternidade prevaleceria na disputa entre duas paternidades socioafetivas, ainda que de origens diversas. A exemplo, uma puramente socioafetiva e outra oriunda de uma paternidade biológica, mas com igual respaldo na afetividade.

Para ilustrar tal impasse, tome-se a situação hipotética - porém muito recorrente - da criança que é criada em convivência diária com seu padrasto, o qual a trata como filha - nos termos do "estado de filiação", analisado anteriormente - porém sem perder vínculo com seu pai biológico e registral. Ou então, a situação da criança que é registrada e amada como filho pelo marido de sua mãe, vindo mais tarde seu pai biológico a descobrir sua existência e empenhando-se em exercer o papel de pai - até então exercido exclusivamente pelo padrasto.

Conforme a lição de Lôbo (2008, p.73):

Essa convivência envolve, às vezes, relações transversais entre filhos oriundos dos relacionamentos anteriores de cada pai e os comuns, dentro do mesmo ambiente familiar, o que provoca incertezas acerca dos possíveis direitos e deveres emergentes, pois é inevitável que o padrasto ou madrasta assuma de fato as funções inerentes da paternidade ou maternidade. (grifou-se) 
O fenômeno crescente das famílias recompostas - aquelas formadas por pessoas que antes integravam outras entidades familiares - figura como uma frequente causa a dar ensejo a multiparentalidade, visto que o padrasto/madrasta inevitavelmente acabam por exercer função análoga à de pais e mães, sem, entretanto, que os genitores biológicos deixem de desempenhar os papéis a eles atribuídos. Neste sentido:

Uma vez desvinculada a função parental da ascendência biológica, sendo a paternidade e a maternidade atividades realizadas em prol do desenvolvimento dos filhos menores, a realidade social brasileira tem mostrado que essas funções podem ser exercidas por "mais de um pai“" ou "mais de uma mãe" simultaneamente, sobretudo, no que toca à dinâmica e ao funcionamento das relações interpessoais travadas em núcleos familiares recompostos, pois é inevitável a participação do pai/mãe afim nas tarefas inerentes ao poder parental, pois ele convive diariamente com a criança; participa dos conflitos familiares, dos momentos de alegria e de comemoração. Também simboliza a autoridade que, geralmente, é compartilhada com o genitor biológico. Por ser integrante da família, sua opinião é relevante, pois a família é funcionalizada à promoção da dignidade de seus membros. (RODRIGUES, 2013, online)

Inúmeras são as situações cabíveis a exemplificar a ocorrência da multiparentalidade, mas o questionamento que se faz em todas elas é o mesmo: deverá a criança optar por uma das paternidades? É necessário que ela - ou o juiz, em seu lugar - proceda a esta escolha e rejeite todo o afeto e amparo que o pai preterido estaria disposto a lhe conceder? Há, dentro do ordenamento brasileiro, espaço para se conceber a multiparentalidade?

Primeiramente, necessário se faz conceituar o instituto da multiparentalidade, o qual se apresenta como bastante novo no contexto do Direito de Família e será o objeto de estudo deste capítulo. Pereira (2013, online) o faz ao dizer:

a multiparentalidade significa o parentesco constituído por múltiplos pais, ou seja, quando um filho tem mais de um pai e/ou mais de uma mãe. Os casos mais comuns são os de padrastos e madrastas exercendo as funções paternas e maternas, paralelamente aos pais biológicos e registrais (...)

Assim o sendo, denota-se que a multiparentalidade caracteriza-se como um fenômeno sociológico contemporâneo através do qual uma mesma pessoa possui plurais paternidades e/ou maternidades. 
Tal fenômeno inegavelmente ocorre no mundo ontológico independentemente da existência ou não de prescrição normativa, todavia, o que se analisará neste estudo é justamente se a multiparentalidade se ajusta ou não ao ordenamento jurídico pátrio, e em que medida este precisa ser flexibilizado para melhor regulá-la.

Por todo o conjunto legislativo analisado na elaboração desta monografia compreendese que não há nenhum impedimento à multiparentalidade no ordenamento pátrio, por outro lado, precisaria ele ser formatado para melhor adequar o instituto em sua moldagem.

De nada adiantaria manter o casamento como um instituto indissolúvel em uma sociedade permeada por concubinatos, da mesma forma, inútil é a tentativa de conservar a paternidade engessada em um modelo de singularidade absoluta diante de realidades flagrantemente multiparentais.

Com efeito, o Direito não é um conjunto enfeixado de normas estagnadas, com definições e conceitos pré-formulados de forma fechada. Emana da própria natureza das relações humanas o caráter aberto e dinâmico do ordenamento jurídico, o que se depreende das constantes mudanças legislativos, doutrinárias e jurisprudências, pautadas no pragnantismo e na evolução da sociedade, notadamente em se tratando do Direito de Família. (ANDRIGUI e KRUEGUER, 2006, p.87)

Outra demonstração de evolução legislativa consiste no advento da Lei no 11.924/2009, a qual atualizou a Lei de Registros Públicos de 1973 de forma a permitir ao enteado (a) que adote o nome de família do padrasto ou madrasta, reconhecendo de forma explícita a socioafetividade. Acerca desta lei comenta-se:

\footnotetext{
Trata-se apenas de uma possibilidade, entre tantas outras, em que o assunto da multiparentalidade vem à tona. A Lei 11.924/2009 já regulamentou a possibilidade de o enteado ou enteada adotar o patronímico da família do padrasto ou da madrasta, porém a questão da multiparentalidade vai além, e questiona-se se seria possível alguém ter em seu registro civil o nome de duas mães ou de dois pais. (PIOLI, 2013, online)
}

O desafio do Direito de Família, neste atual momento, revela-se em estender a proteção jurídica hoje destinada a uma única modalidade de vínculo paterno-filial - qual seja, a paternidade singular- aos plurais vínculos paternos que empiricamente venham a ocorrer no mundo dos fatos. 
Neste diapasão, Tartuce (2016, p.76) afirma que a multiparentalidade é um caminho sem volta na modernização do direito de família, e que representa uma consolidação da afetividade como princípio jurídico em nosso sistema. Em suas palavras:

O que se tem visto na jurisprudência até aqui é uma escolha de Sofia, entre o vínculo biológico e o socioafetivo, o que não pode prosperar em muitas situações fáticas. Como interroga a doutrina consultada, por que não seria possível ter a pessoa dois pais ou duas mães no registro civil, para todos os fins jurídicos, inclusive familiares e sucessórios?

Destarte, muito embora para melhor regular os casos de multiparentalidade seria ideal uma reforma na legislação ordinária, pode-se dizer que a Constituição Federal, alicerce basilar de todo o ordenamento jurídico, já abrange em seu espectro de proteção tal instituto, visto que princípios como o da dignidade da pessoa humana, da solidariedade familiar, do pluralismo das entidades familiares, da convivência familiar, da paternidade responsável e, fundamentalmente, da afetividade, convergem todos na direção da aceitação da cumulação de paternidades.

Assim o sendo, uma vez que esteja o referido instituto contemplado pela Constituição, não há como alegar que o Ordenamento Jurídico brasileiro não o possa recepcionar, visto que todo e qualquer outro diploma normativo estará necessariamente abaixo da Carta Magna em uma divisão hierárquica de normas.

Este ponto de equilíbrio é o que se persegue nesta presente monografia, sendo que, uma vez reconhecida a existência simultânea de duas paternidades distintas, possam ambas surtir os devidos efeitos jurídicos.

Ademais, a de se considerar que, independentemente da ocorrência destes efeitos jurídicos, o registro da paternidade continuaria a ser indispensável, visto que atribui um outro aspecto fundamental para todo o ordenamento pátrio, qual seja, a dignidade da pessoa humana. Segundo Tepedino (1997, p.48):

(...) a milenar proteção da família como instituição, unidade de produção e reprodução dos valores culturais, éticos, religiosos e econômicos, dá lugar à tutela essencialmente funcionalizada à dignidade de seus membros, em particular no que concerne ao desenvolvimento da personalidade dos filhos. (grifou-se)

Necessário neste vértice considerar que, embora primordial, não é apenas o interesse da criança cuja paternidade se discute que está em jogo, mas também de ambos os pais que a 
pleiteiam, visto que um logrará com o êxito todas as prerrogativas de pai enquanto o outro, com a derrota, não terá nem mesmo acesso à criança.

O genitor afetivo teria sua dignidade violada quando todo o seu afeto e dedicação a seu filho não fossem considerados para efeitos de manter ou incluir seu nome no registro de nascimento de seu filho.

Neste sentido, prega Póvoas (2012, p.78) que "não há como negar que fere a dignidade do pai afetivo e viola o princípio da afetividade simplesmente extirpar a relação parental entre ele e aquela pessoa que sempre teve como filho, por não haver entre eles liame biológico".

Doutro vértice, feriria igualmente a dignidade humana da pessoa do pai biológico vir a ser excluído do registro de nascimento daquele que carrega sua herança genética, uma vez que houvesse afeto presente nesta relação ou ao menos disposição deste pai em afeiçoar-se a seu filho.

Assim o sendo, a normatização do Direito de Família contemplando apenas a dimensão genética consistira em uma abstração, visto que deixaria desamparadas as realidades ontológicas e afetivas. Já a desconsideração da paternidade biológica também não traria nenhuma vantagem aos participantes da relação paterno-filial.

Tal teoria já vem repercutindo nos tribunais, como se demonstra através do entendimento do desembargador Danielli em sede de julgamento dos Embargos Infringentes de n. 2010.054045-7:

EMBARGOS INFRINGENTES. INVESTIGAÇÃO DE PATERNIDADE

CUMULADA COM PETIÇÃO DE HERANÇA. PATERNIDADE REGISTRAL E SOCIOLÓGICA QUE NÃO EXCLUI A CONSANGUÍNEA, CONFIRMADA POR PROVA PERICIAL. CONSTRUÇÃO CONSTITUCIONAL DE UM ESTATUTO DA FILIAÇÃO QUE COMPATIBILIZE OS DIFERENTES ASPECTOS DO 56 SER, QUAIS SEJAM, O GENÉTICO, O AFETIVO E O ONTOLÓGICO. TEORIA TRIDIMENSIONAL DA PATERNIDADE. POSSIBILIDADE DE JURIDICIZAÇÃO DA HISTÓRIA DE VIDA DO SER HUMANO. IMPOSSIBILIDADE DE HIERARQUIZAR-SE AS FORMAS DE PATERNIDADE, GERANDO CADA UMA, A SEU TEMPO E MODO OS EFEITOS JURÍDICOS PERTINENTES, COMO NOME E HERANÇA. RECURSO CONHECIDO E PROVIDO. (BRASIL, 2011) (grifou-se).

Contudo, muito embora a dignidade dos pais deva ser considerada no deslinde das questões envolvendo multiparentalidade, imperioso reconhecer que o aspecto principal a ser 
analisado na determinação da mesma vem a ser o interesse da criança e do adolescente cuja paternidade se discute.

\section{CONSEQUÊNCIAS REGISTRAIS DA CUMULAÇÃO DE PATERNIDADES}

Inútil seria o reconhecimento do fenômeno da multiparentalidade se esse não viesse a surtir efeitos jurídicos na vida dos envolvidos na relação multiparental. Póvoas (2012, p.89) sustenta que "o reconhecimento só judicial da multiparentalidade, sem a inclusão de todos no registro de nascimento da criança, cria mais um problema do que uma solução".

Na mesma esteira, Rodrigues e Teixeira (2010, p.89) lecionam: “a multiparentalidade inaugura um novo paradigma do Direito Parental, no ordenamento brasileiro. Para que ela se operacionalize, contudo, é necessário que seja exteriorizada através de modificações no registro de nascimento".

De fato, a inclusão dos nomes dos eventuais pais ou mães que venham a ser reconhecidos hão de constar no registro de nascimento da pessoa, nos termos da Lei Federal $n^{\circ}$ 6.015/73, conhecida popularmente como Lei de Registros Públicos (BRASIL, 1973), responsável pelo registro da filiação e pelos efeitos jurídicos que essa passa a emanar.

Ocorre, todavia, que a Lei de Registros Públicos não faz previsão acerca da hipótese de multiparentalidade, o que é bastante óbvio, ao considerar-se que se trata de uma lei de 1973, enquanto o fenômeno da multiparentalidade, por outro lado, é bastante recente, fruto da sociedade contemporânea em que vivemos e de suas conquistas, a exemplo do avento dos exames de DNA e do paradigma da socioafetividade.

Todavia, esta lacuna jurídica no âmbito da legislação ordinária não se demonstra como um empecilho ao exercício da multiparentalidade, visto que o referido instituto é contemplado pelos princípios constitucionais, os quais, como se sabe, são hierarquicamente superiores dentro do ordenamento jurídico.

Neste sentido leciona Póvoas (2012, p.90), ao dispor que “a lei Registral, infraconstitucional, jamais pode ser óbice ao reconhecimento da dupla filiação parental, porque esta é baseada em princípios constitucionais superiores a ela”. Na mesma esteira posiciona-se Welter (2009, online):

(...) quando se cuida de ação de estado, de direito da personalidade, indisponível, imprescritível, intangível, fundamental à existência humana, como é o reconhecimento

Revista de Direito de Família e Sucessão | e-ISSN: 2526-0227 | Porto Alegre | v. 4 | n. 2 | p. 120 - 137 | Jul/Dez. 2018 
das paternidades genética e socioafetiva, não se deve buscar compreender o ser humano com base no direito registral, que prevê a existência de um pai e uma mãe, e sim na realidade da vida de quem tem, por exemplo, quatro pais (dois genéticos e dois afetivos), atendendo sempre aos princípios fundamentais da cidadania, da afetividade, da convivência em família genética e afetiva e da dignidade humana, que estão compreendidos na condição humana tridimensional.

Rodrigues e Teixeira (2010, p.106), ao abordarem o tema multiparentalidade, contribuem dizendo que "O registro não pode ser um óbice para a sua efetivação, considerando que sua função é refletir a verdade real; e, se a verdade real concretiza-se no fato de várias pessoas exercerem funções parentais na vida dos filhos, o registro deve refletir esta realidade".

É neste vértice que reside a importância do caráter registral da paternidade, visto que, muito embora o aspecto material da paternidade resida nos critérios afetivos e biológicos, será somente o critério registral que cumprirá os requisitos da paternidade no plano formal, os quais, por sua vez, resultarão no estado da pessoa natural, vindo a operar no mundo dos fatos as consequências morais e patrimoniais advindas do vínculo paterno-filial.

Toda e qualquer alteração que ocasione modificação no estado da pessoa natural deve ser averbado junto ao Registro Público. No que concerne à filiação, o Código Civil de 2002, logo em seu artigo 10, inciso II, já trás determinação expressa da necessidade de averbação em registro público.

\footnotetext{
Art. 10. Far-se-á averbação em registro público:

I - das sentenças que decretarem a nulidade ou anulação do casamento, o divórcio, a separação judicial e o restabelecimento da sociedade conjugal;

II - dos atos judiciais ou extrajudiciais que declararem ou reconhecerem a filiação; (grifou-se)
}

Destarte, a juridicidade conferida à relação através do registro civil de nascimento certifica ao instituto filiação segurança jurídica, uma vez que tenha se procedido dentro dos parâmetros do ato jurídico perfeito.

Segundo Amaral (2000, p.240), a função do registro civil "é dar autenticidade, segurança e eficácia aos fatos jurídicos de maior relevância para a vida e os interesses dos sujeitos de direito". Evidente que a filiação é um dos mais relevantes fatos jurídicos ocorridos na vida de qualquer pessoa, sendo indispensável, deste modo, que esta conste no registro civil do indivíduo, de forma a garantir-lhe todos os efeitos jurídicos que dela decorrem e que já foram 
anteriormente estudados nesta monografia, a exemplo: o estabelecimento do poder familiar, o direito de vistas, a obrigação de prestar alimentos, o direito sucessório, dentre outros.

Ademais, embora não seja o único meio, é através do registro civil de nascimento que se faz prova da filiação, conforme estabelecido no artigo 1.603 do Código Civil de 2002. Acerca deste aspecto Póvoas (2012, p.89) leciona:

\footnotetext{
Ora, pela certidão extraída do registro comprova-se a filiação de forma direta, conforme dicção do art. 1.603, do Código Civil. O registro não é a única, mas é a mais fácil maneira de se provar a paternidade/maternidade, servindo de base para vários atos da vida civil, inclusive os garantidores de direitos dos menores - previdenciários, por exemplo - pois estabelece de forma incontestável por terceiros a relação paterno/materno filial.
}

Assim o sendo, a averbação da multiparentalidade reconhecida através de ação declaratória se dará nos termos do artigo 97 da Lei de Registros Públicos (BRASIL, 1973):

Art. 97. A averbação será feita pelo oficial do cartório em que constar o assento à vista da carta de sentença, de mandado ou de petição acompanhada de certidão ou documento legal e autêntico, com audiência do Ministério Público.

Outro dado a corroborar o caráter registral da multiparentalidade consiste no modelo fixado pelo Conselho Nacional de Justiça em 2009 para a expedição de certidões de nascimento, no qual estabeleceu como exigência o preenchimento do campo filiação sem, entretanto, delimitar quantas ou quais pessoas figurariam neste campo.

Ademais, há de se considerar também o preceito constitucional que garante tratamento isonômico entre as relações de parentesco, de forma que os núcleos familiares constituídos pela forma biparental (pai e mãe) não podem auferir vantagens, frente aos outros (multiparentais, monoparentais, família avoenga, etc.).

Assim, uma vez reconhecida a juridicidade da multiparentalidade e a sua exteriorização através da averbação no registro de nascimento, passa-se a análise das consequências que o caráter registral gera.

A primeira e mais evidentes destas é o estabelecimento do vínculo de parentesco.

Quando da ocorrência de multiparentalidade, Póvoas (2012, p.93) prega que a criança cuja paternidade/maternidade houvesse sido duplicada "teria parentesco em linhas reta e colateral (até quarto grau) com a família do pai/mãe afetivos e pai/mãe biológicos, valendo este 
grau de parentesco para todas as hipóteses previstas em lei, inclusive impedimentos matrimoniais (art. 1.523, do CC) e sucessórios".

O segundo efeito imediato a ser analisado consiste no nome, ponto no qual não se encontra muita dificuldade, visto que se trata de um direito personalíssimo com fulcro na dignidade da pessoa humana.

Necessário apontar, ainda, para a reciprocidade absoluta dos efeitos patrimoniais, quais sejam, o direito à herança e à prestação alimentícia, visto que, muito embora tal se configure em um primeiro momento como uma dupla vantagem ao filho que possui dois pais, poderá, na vida adulta, se converter em um duplo dever.

Por todo o exposto, conclui-se que a paternidade só se completa quando apreciados todos os três critérios que a completam, quais sejam: o biológico, o afetivo e o registral. Logo, não cabe mais em nossa atual Sociedade privar crianças e adolescentes de manter convívio com todos seus pais - sejam quantos forem - sacrificando valores constitucionais em nome da manutenção rígida de um modelo singular de paternidade.

\section{CONCLUSÃO}

O instituto familiar se apresenta como a mais antiga unidade social da História, vindo, todavia, a sofrer modificações de acordo com as alterações de comportamento humano, bem como com a queda de dogmas que não mais se compatibilizam com a atual Sociedade.

Deste modo, a família patriarcal, matrimonializada, cujos interesses patrimoniais se sobrepujavam, foi substituída pela família eudemonista, que possui como finalidade o pleno desenvolvimento da personalidade de seus membros. Tal família funda-se e norteia-se em diversos princípios constitucionais, mas em especial no princípio da dignidade da pessoa humana, norteador basilar de todo o nosso ordenamento jurídico, e no princípio da afetividade, o qual atribui ao afeto status de bem jurídico digno de proteção, e o torna determinante no deslinde de muitas questões em nossos tribunais, em especial na seara familiar.

Acompanhando esses progressos, a filiação, enquanto instituto do Direito de Família, se demonstra um conceito igualmente dinâmico no mundo jurídico, visto que sua evolução histórica explicita o quão já se aperfeiçoou em conceder tratamento isonômico aos filhos, deixando de descrimina-los entre legítimos e ilegítimos de acordo com sua origem. Neste 
aspecto, impossível não citar a Constituição Federal de 1988 como a responsável direta por esta conquista, refletindo tal avanço na renovação legislativa e jurisprudencial de todo o país.

Entretanto, embora não haja qualquer diferenciação depreciativa quanto à qualidade de filho, contemporaneamente vem o instituto a receber diferentes classificações de acordo com o critério que se adote em sua determinação, quais sejam: o registral, o biológico e o afetivo. Denota-se que o primeiro destes resulta da vasta utilização da presunção pater is est - resumida, sucintamente, na ideia de que o marido da mãe sempre será o pai do filho desta. Tal premissa, todavia, esbarrou no advento científico dos exames de DNA, que conferiram precisão técnica acerca da transmissão hereditária de carga genética, passando a definir a paternidade de acordo com um critério biológico ao invés do meramente jurídico. Por fim, surgiu e se consubstanciou como uma construção cultural fruto da sociedade contemporânea o critério afetivo, que funcionalizou o conceito de pai em razão do papel que este exerce na vida de seu filho, respaldado no princípio da afetividade.

Neste diapasão, ressalta-se a transição entre os paradigmas do biologismo e da socioafetividade, e os conflitos que passam a surgir no campo jurisprudencial quando da colisão entre paternidades fundadas em diferentes critérios. Neste interregno, observa-se pela análise constitucional que inexiste hierarquia entre tais critérios, todavia, conclui-se que igualmente inexiste paternidade que não se respalde na afetividade, visto que esta é inerente à função de pai no seio da família eudemonista.

Assim o sendo, não se admite a desconstrução do vínculo socioafetivo uma vez instalado, sendo impossível desconstituir a paternidade registrada, visto ser este um ato personalíssimo, irrevogável e irretratável, exceto se maculado por erro ou vício da vontade. Logo, quando da ocorrência do registro de filiação decorrerão todos os efeitos que esta gera, quais sejam: o vínculo de parentalidade - devidamente acompanhado por todos os impedimentos que este ocasiona -, o direito ao nome, o estabelecimento do poder familiar, a fixação da guarda e das visitas, o direito aos alimentos, bem como o de ser chamado à ordem sucessória.

Por outro lado, igualmente impossível se demonstra desconstituir a paternidade biológica, uma vez que pai e filho se demonstrem dispostos a estreitar seus laços e a criar vínculos. Ademais, não pode o genitor ausentar-se de suas responsabilidades patrimoniais contraídas em relação a seu filho alegando a pré-existência de outra paternidade de natureza puramente socioafetiva já consolidada, bem como a ele não pode ser negada a oportunidade de se aproximar de seu filho em virtude deste mesmo argumento. 
Por fim, fundamental observar o deslinde da questão pelo enfoque da dignidade da pessoa humana de todos os envolvidos, em especial da criança e do adolescente, contemplados pela especial proteção prevista pelo artigo 227 da Constituição Federal e reforçada pelo Estatuto da Criança e Adolescente (Lei 8.069 de 1990).

Assim o sendo, surge a multiparentalidade como a melhor opção a resolver os casos em que, independentemente da existência de regulamentação normativa, ela efetivamente ocorre, ou seja, em que na realidade fática empiricamente se verifique que aquela pessoa possui dois diferentes pais ou mães.

Tal opção se demonstra como a melhor alternativa, não apenas para os magistrados no deslinde das questões acerca do conflito de paternidades fundadas em diferentes critérios, mas principalmente paras àqueles cuja paternidade é discutida, visto que privilegia a prevalência absoluta dos interesses da criança e do adolescente pela dupla oferta de afeto e garantias.

Já se observa, ainda que de forma tímida, decisões judiciais contemplando a multiparentalidade e determinando a averbação de dois pais e/ou duas mães na certidão de nascimento do filho, sendo imperioso, nesse ponto, destacar que é do caráter registral da filiação que passarão a emanar todos os efeitos jurídicos desta, os quais deverão se operar em harmonia entre as duas paternidades declaradas.

Nesse vértice, oportuno destacar que, muito embora esta duplicidade registral venha a ocasionar um duplo bônus aos filhos contemplados pela dupla paternidade, poderá, no futuro, tornar-se um duplo encargo, vislumbrada a inexorável reciprocidade que permeia os alimentos e a vocação sucessória.

Logo, deve o ordenamento jurídico se adaptar a esta nova realidade que se instaura na vida quotidiana de tantas famílias brasileiras, visto que a multiparentalidade já possui respaldo nos princípios constitucionais, não podendo de forma alguma a legislação infraconstitucional, a exemplo da Lei de Registros Públicos (Lei $n^{\circ}$ 6.015/73), se tornar um óbice a aplicação do instituto.

Diante de todo o exposto, conclui-se que a filiação apenas se completa quando apreciados todos os seus critérios, ainda que representados por pessoas distintas, vindo a paternidade biológica e a paternidade socioafetiva a se perfectibilizarem na paternidade registral, todas com respaldo na dignidade da pessoa humana e na afetividade. 


\section{REFERÊNCIAS}

AMARAL, Francisco. Direito Civil - Introdução. 3. Ed. Rio de Janeiro: Renovar, 2000.

ALMEIDA, Renata Barbosa de; RORIGUES JÚNIOR, Walsir Edson. Direito civil: famílias. 2. ed. São Paulo: Atlas, 2012.

ANDRIGHI, Fátima Nancy; KRUGER, Cátia Denise Gress. Coexistência entre a socioafetividade e a identidade biológica - uma reflexão. In: Família e Jurisdição II. BASTOS, Eliane Pereira; LUZ, Antônio Fernandes da. (coords). Belo Horizonte: Del Rey, 2008.

BRASIL. Constituição da República Federativa do Brasil: promulgada em 5 de outubro de 1988. Brasília: Senado Federal, 2006.

CYSNE, Renata Nepomuceno. Os laços afetivos como valor jurídico: na questão da paternidade socioafetiva. In: Família e Jurisdição II. BASTOS, Eliane Pereira; LUZ, Antônio Fernandes da. (coords). Belo Horizonte: Del Rey, 2008.

LÔBO, Paulo Luiz Netto. Direito civil: famílias. São Paulo: Saraiva, 2008.

FACHIN, Luiz Edson, Da paternidade: relação biológica e afetiva. Belo Horizonte, Del Rey, 1996.

SANTOS, Marlouve Moreno Sampaio. Reflexões sobre a paternidade nas relações familiares sob a ótica do direito e da psicanálise. In: Família e Jurisdição III. BASTOS, Eliane Pereira; ASSIS, Arnaldo Camanho de; SANTOS, Marlouve Moreno Sampaio. (coords). Belo Horizonte: Del Rey, 2009.

MADALENO, Rolf. Curso de Direito de Familia. Rio de Janeiro, Forense, 2011.

PEREIRA, Rodrigo da Cunha. Princípios fundamentais norteadores para o Direito de Família. Belo Horizonte: Del Rey, 2006.

PÓVOAS, Mauricio Cavallazzi. Multiparentalidade: A possibilidade de múltipla filiação registral e seus efeitos. 1 ed. Florianópolis: Conceito Editorial, 2012.

RODRIGUES, Renata de Lima. Multiparentalidade e a nova decisão do STF sobre a prevalência da verdade socioafetiva sobre a verdade biológica na filiação. Disponível em: <https://www.ibijus.com/blog/12-multiparentalidade-e-a-nova-decisao-do-stf-sobrea-

Revista de Direito de Família e Sucessão | e-ISSN: 2526-0227 | Porto Alegre | v. 4 | n. 2 | p. 120-137 | Jul/Dez. 2018 
>prevalencia-da-verdade-socioafetiva-sobre-a-verdade-biologica-na-filiacao Acesso em 22 de abril de 2018

TARTUCE, Flávio. Direito civil, v. 5: Direito de Família. 11. ed. rev., atual. e ampl. - Rio de Janeiro: Forense, 2016.

TEPEDINO, Gustavo In: PEREIRA, Rodrigo da Cunha (coord.) Direito de família contemporâneo. Belo Horizonte: Del Rey.

TEIXEIRA, Ana Carolina Brochado; RODRIGUES, Renata de Lima. Multiparentalidade como fenômeno jurídico contemporâneo. Revista Brasileira de Direito das Famílias e Sucessões, v.14, 2010.

WELTER, Belmiro Pedro. Teoria tridimensional do direito de família: reconhecimento de todos os direitos das filiações genética e socioafetiva. Revista Brasileira de Direito das Famílias e Sucessões. Porto Alegre: Magister; Belo Horizonte: IBDFAM, ano 10, n. 8, p. 113, fev./mar. 2009.

Lei n. 10.406, de 10 de janeiro de 2002. Institui o Código Civil. Disponível em: <http://www.planalto.gov.br/ccivil_03/leis/2002/L10406.htm> Acesso em: 20 de abril de 2018.

Lei n. 8.069, de 13 de julho de 1990. Dispõe sobre o Estatuto da Criança e do Adolescente e dá outras providências. Disponível em: <http://www.planalto.gov.br/ccivil_03/leis/L8069.htm> Acesso em: 13 de junho de 2018.

Lei n. 6.015, de 31 de dezembro de 1973. Dispõe sobre os registros públicos, e dá outras providências. Disponível em: <http://www.planalto.gov.br/ccivil_03/LEIS/L6015.htm>. Acesso em: 15 de junho de 2018.

Superior Tribunal de Justiça. Recurso Especial n. 1000356 / SP. Ementa: Direito civil. Família. Recurso Especial. Ação de anulação de registro de nascimento. Ausência de vício de consentimento.Maternidade socioafetiva. Situação consolidada. Preponderância dapreservação da estabilidade familiar.[...]. Relator: Des. Nancy Andrighi. Julgamento 25 maio 2012.

Superior Tribunal de Justiça. Recurso Especial n. 945283 / RN. Ementa: DIREITO DE FAMÍlIA. GUARDA DE MENOR PLEITEADA POR AVÓS. POSSIBILIDADE. PREVALÊNCIA ABSOLUTA DO INTERESSE DA CRIANÇA E DO ADOLESCENTE OBSERVADA. [...]. Relator: Des. Luis Felipe Salomão. Julgamento 28 set. 2009. 
Superior Tribunal de Justiça, Ac 4 ${ }^{\mathrm{a}}$ T., REsp 1137425 DF 2009/0081828-5, rel. Min

Raul Araújo. j. em 16.8.11, DJe 06.09.11 . Poder Judiciário do Estado de Rondônia.

Comarca de Ariquemes. Ação de Investigação de Paternidade cumulada com Anulação de Registro Civil n. 0012530-95.2010.8.22.0002. Requerente A. A. B. e Requeridos E. da S. S. e M. da S. B. Juíza Deisy Cristhian Lorena de Oliveira Ferraz. 13 de março de 2012. 74. 